\title{
Pickling of chanterelle Cantharellus cibarius mushrooms highly reduce cadmium contamination
}

\author{
Malgorzata Drewnowska $^{1}$ • Anetta Hanć ${ }^{2}$ - Danuta Barałkiewicz ${ }^{2} \cdot$ Jerzy Falandysz $^{1}$ (D)
}

Received: 31 March 2017 / Accepted: 24 July 2017 /Published online: 1 August 2017

(C) The Author(s) 2017. This article is an open access publication

\begin{abstract}
Mushrooms are considered as potential bioremediation agents in soil polluted with heavy metals, while many species which efficiently accumulate them in flesh are edible. Question is if there is any possible culinary use of edible mushrooms with high heavy metal contents? This study aimed to investigate and discuss a fate of cadmium $(\mathrm{Cd})$ in common household-treated fruitbodies of common chanterelle Cantharellus cibarius. The samples of Cantharellus cibarius Fr. were collected from five spatially distanced sites in Poland in 2011-2012. We examined from 267 to 358 fruiting bodies per collection, and in total 1565 fruiting bodies were used. Cadmium in fungal materials from all treatments and processes (mushrooms dried, deep frozen, blanched and pickled) was determined using validated methods by inductively coupled plasma mass spectrometry with dynamic reaction cell. Blanching of fresh chanterelles caused decrease of Cd by around $11 \pm 7$ to $36 \pm 7 \%$, while blanching of deepfrozen mushrooms by around $40 \pm 6 \%$. A rate of Cd decrease in chanterelles was similar when the fruiting bodies were blanched for 5 or $15 \mathrm{~min}$ and when used was potable or deionized water. Pickling of blanched chanterelles with a diluted vinegar marinade had a pronounced effect on further removal of Cd. Blanched chanterelles when pickled lost an extra 37$71 \%$ of $\mathrm{Cd}$. Total leaching rate of $\mathrm{Cd}$ from fresh or deep-
\end{abstract}

Responsible editor: Elena Maestri

Jerzy Falandysz

jerzy.falandysz@gmail.com

1 Laboratory of Environmental Chemistry and Ecotoxicology, Gdańsk University, 63 Wita Stwosza Str, 80-308 Gdańsk, Poland

2 Laboratory of Trace Element Analysis by Spectroscopy Method, Adam Mickiewicz University, Umultowska 89b, 61-614 Poznań, PL, Poland frozen fruitbodies of chanterelle when blanched and further pickled was between $77 \pm 7$ and $91 \pm 4 \%$. Blanching and pickling highly decreased content of $\mathrm{Cd}$ in C. cibarius.

Keywords Heavy metals $\cdot$ Mushroom $\cdot$ Food technology · Environmental pollution $\cdot$ Risk assessment

Different species of mushrooms (basidiomycetes) from the wild and cultivated due to specificities in their physiology and/or an element abundance in a substrate may accumulate at elevated concentrations or hyper-accumulate (high values of bio-concentration factor) in fruitbodies the toxic elements, e.g. Ag, Cd, Hg, Pb or As (Borovička et al. 2007; Falandysz 2017; Falandysz and Rizal, 2016; Falandysz et al. 1994; Mleczek et al. 2015b). Also $\mathrm{Cu}$ and Zn, which are essential bio-elements, can be well bio-concentrated by mushrooms in fruitbodies (Kojta et al. 2016). For a mushroom enriched with a heavy metal, an option can be culinary use in aims to decrease contamination if fulfilled are the health safety conditions.

Accumulation or hyper-accumulation of a heavy metal by the mushroom may imply on possible usefulness of a species in mycoremediation technology of polluted soils. In context of mycoremediation, Agaricus urinascens (former name Agaricus macrosporus) and Coprinus comatus were suggested as possible candidates due to their capacity for bioconcentration of $\mathrm{Cd}, \mathrm{Cu}, \mathrm{Hg}$ and $\mathrm{Pb}$ (Cen et al. 2012; Falandysz 2016; García et al. 2005). An ability of a given species of mushroom to absorb by mycelium an element from a soil substrate and accumulate it in fruitbodies can be enhanced by an external application of a chelating agent (Cen et al. 2012). So far is unknown any example of a molecular modification aiming to increase efficiency of heavy metal absorption and sequestration in fruitbody by modification of a 
gene encoding the transporter or binding molecules. The metallothionein-like ligands were identified for $\mathrm{Ag}, \mathrm{Cd}$ or $\mathrm{Cu}$ in some mushrooms by Münger and Lerch (1985) and Osobová et al. (2011). As a binding agent of Cd in Agaricus urinascens (former name Agaricus macrosporus), mycophosphatin was identified-a sulphur-free, nonmetallothionein-like ligand (Schmitt and Meisch, 1985).

The question arise if there is any possible culinary use of edible mushrooms with high heavy metal content in flesh, e.g. species-specific accumulators, foraged in areas with geochemical anomaly, affected by anthropogenic emissions or harvested from the mycoremediation process? For example, the mushroom Suillus variegatus (common name variegated bolete) under a typical environmental condition can accumulate $\mathrm{Fe}$ in fruitbodies at up to $0.41 \%$ dry biomass (Falandysz et al. 2001). A scale of an enrichment that could be attractive for recovery of any noble or rare earth element but certainly not of Fe that is too common.

Cadmium apart from the $\mathrm{Ag}, \mathrm{Hg}$ or $\mathrm{Pb}$ can be well accumulated and high in certain species of mushrooms that are grown in backgrounds (Árvay et al. 2014; BrzezichaCirocka et al. 2016; Falandysz et al. 2003, 2007a, b and 2017b; García et al. 2009; Kojta et al. 2016; Melgar et al. 1998 and 2016; Mędyk et al. 2017; Stefanović et al. 2016) or polluted areas, and also if grown in agroindustrial wastes (Falandysz 2017; Favero et al. 1990; Mleczek et al. 2015a). Cadmium is one of the priority inorganic environmental and food contaminants. Cooking has a potential to reduce the levels of $\mathrm{Cd}$ or other heavy metal in the mushrooms to a level low enough for safe consumption.

Deep freezing, thawing, slicing, drying, re-soaking or drying - grinding - macerating as well as acidification or the presence of chelating agents increase the leaching of $\mathrm{Mn}, \mathrm{Fe}, \mathrm{Zn}$ and $\mathrm{Cu}$ from blanched champignon Agaricus bisporus, while there is a deficit of the data for Cd (Biekman et al. 1996; Coskuner and Özdemir, 1997 and 2000; Drewnowska et al. 2017).

Blanching and pickling are traditional cooking methods for many mushrooms, and this study aimed to examine if blanching and pickling can reduce $\mathrm{Cd}$ in consumed mushrooms (chanterelles). An insight into a fate of $\mathrm{Cd}$ in processed and culinary-treated mushrooms can matter from a general food safety issue point of view regarding their nutritional and potential risk aspects and also for their potential use in bio-remediation or mycoremediation technology.

\section{Materials and methods}

\section{Mushroom collection, preparation, household treatment and analysis}

The samples of Cantharellus cibarius Fr. were collected from five spatially distanced sites (from 267 to 358 fruiting bodies per collection, and in total 1565 fruiting bodies were used) in Poland in 2011-2012. The sampling sites were the background areas at the locations: Jastrzębia Góra, Darżlubska Wilderness, Łapino, Tucholskie Pinewoods and Kościerzyna forest in the north-central region of Poland (Falandysz and Drewnowska, 2017). Traditionally, mushrooms were collected with bare hands and stored shortly in wooden baskets. Fruitbodies were rinsed with cold tap water and drained. Next, each fruitbody in collection from a particular site was sliced into four or three parts (vertical cuts using a plastic knife), which were pooled accordingly. In total, 36 composite subsamples (separated per site) were prepared from those mushrooms for experiments.

\section{Household treatment}

Several experiments have been performed to examine an impact of processing and culinary treatment on fate of $\mathrm{Cd}$ in chanterelle (dried, frozen, blanched and pickled) mushrooms. A subsample of fresh and deep-frozen mushrooms from three locations were dried conventionally in an electrically heated dryer or freeze-dried, and further ground and subjected for $\mathrm{Cd}$ analysis.

Deionized water free of $\mathrm{Cd}$, potable bottled water (Fonte spring from the location Nieszawa in Poland) free of a detectable $\mathrm{Cd}$ and a commercial spirit vinegar (acidity $10 \%$ ) were used as media in the blanching and pickling experiments.

\section{Conventional drying}

From each sample set, the subsamples of fresh individuals were selected. Mushrooms were placed into plastic trays of an electrically heated commercial dryer (dehydrator for vegetables, model MSG-01, MPM Product, Milanówek, Poland) and dried at $65{ }^{\circ} \mathrm{C}$ to constant mass. Dried fungal materials were ground using porcelain pestles and mortars that were cleaned by hand washing using laboratory brush, deionized water and detergent and further rinsed with distilled water and dried in an electrically heated laboratory dryer at $105^{\circ} \mathrm{C}$, and next were transferred into screw-capped plastic tubes (VWR®, Ultra High Performance, $15 \mathrm{~mL}$ ), then sealed in polyethylene bags and kept in dry and clean condition in a storage room until analysis. These fungal materials were considered as the reference samples for householdtreated mushrooms (Falandysz and Drewnowska, 2017).

\section{Frozen mushrooms}

Two subsamples of the fruiting bodies of $C$. cibarius were divided into portions and kept frozen at $-20^{\circ} \mathrm{C}$ for 1 month. Frozen mushrooms were further blanched or blanched and pickled. 


\section{Blanching}

Fresh or frozen mushrooms were blanched respectively for 5 to 15 min using gently boiling distilled water $(150 \mathrm{~mL})$ in glass bakers or with mineral water $(150 \mathrm{~mL})$ in a stainless steel pot. The mushroom to water volume in the experiments was as 1:5. After blanching, mushrooms were drained and the subsamples were taken and freeze-dried, ground and kept in screw-capped plastic tubes in sealed polyethylene bags for trace elements determination.

\section{Pickling}

The blanched $C$. cibarius samples were pickled using a vinegar-based marinade. The spirit vinegar of $10 \%$ acidity (in glass bottle with an aluminium screw cap and polyethylene gasket, $0.5 \mathrm{~L}$ ) used for preparation of the marinade was bought in a grocery shop. The marinade was made by dilution of a vinegar respectively with deionized and potable water in proportion 1:4. Mushrooms were pickled in glass bakers $(150 \mathrm{~mL})$. Bakers filled with mushrooms and marinade were tightly sealed using a plastic foil from the top and kept in room temperature for 1 month. Next, mushrooms were drained, lyophilized and ground-using porcelain pestle and mortar. Grounded mushrooms were packed into screw-capped plastic tubes (VWR®), Ultra High Performance, $15 \mathrm{~mL}$ ). Tubes with a fungal material were further packed into a foil bag, which was sealed, and kept in dry and clean condition in a storage room until further analysis.

\section{Dry biomass determination}

Dry biomass content was determined for each sample of mushrooms - fresh and processed frozen, blanched and pickled (PN-90A-7510/03, 2003).

\section{Spectroscopic analyses}

Cadmium in fungal materials from all treatments and processes was determined using validated methods by inductively coupled plasma mass spectrometry with dynamic reaction cell (ICP-DRC-MS, ELAN DRC II ICP-MS) (Falandysz et al. 2017a). The fungal materials were wet-digested with a solution of concentrated nitric acid in pressurized vessels made of poly-tetrafluoroethylene (PTFE) with aid of microwaves. In the same way, several certified reference materials of known content of $\mathrm{Cd}$ and the procedural blanks were examined (Table 1) (Falandysz et al. 2017a). The method limit of quantification (LOQ) of $\mathrm{Cd}$ in aqueous solution by the ICP-MS measurement was $1 \mu \mathrm{g} / \mathrm{l}$.

\section{Results and discussion}

\section{Cadmium in $C$. cibarius}

The cadmium concentrations in $C$. cibarius in this study were in range $0.17 \pm 0.01$ to $0.27 \pm 0.01-\mathrm{mg} \mathrm{kg}^{-1}$ dry biomass $(\mathrm{db})$. Cadmium concentrations in $C$. cibarius from the sites across Europe usually not exceeded a value of $1 \mathrm{mg} \mathrm{kg}^{-1}$ $\mathrm{db}$, while when foraged from the montane sites somewhere or from the sites impacted by the metal smelting activities showed concentrations above $1 \mathrm{mg} \mathrm{kg}^{-1} \mathrm{db}$ (Drewnowska and Falandysz 2015; Falandysz and Drewnowska 2015; Falandysz et al. 2012).

\section{Loss of biomass in process of blanching and pickling}

Conventional drying of fresh mushrooms at $65^{\circ} \mathrm{C}$ to constant biomass removes most of water and some well volatile organic components, while freeze-drying basically removes moisture. In this study, fresh and sliced fruiting bodies of $C$. cibarius when blanched lost on the average $36 \%$ of biomass, while when they were further pickled they lost in total $40 \%$ of the original biomass. Frozen fruiting bodies of the $C$. cibarius when blanched lost $62 \%$ of biomass, while when further pickled they lost $74 \%$ of biomass (largely water and water soluble compounds).

\section{Impact of blanching and pickling on content of cadmium in $C$. cibarius}

Blanching of sliced fresh fruiting bodies of $C$. cibarius caused decrease of the Cd content by $11 \pm 7$ to $36 \pm 7 \%$ and of sliced frozen fruiting bodies by $40 \pm 6 \%$. In the next treatment step, the pickling of initially blanched fresh fruiting bodies caused further loss of cadmium in the range of $42-71 \%$, median values $(p<0.05$, Mann-Whitney $U$ test; Table 2$)$. Total rate of $\mathrm{Cd}$ leaching from the blanched and further pickled $C$. cibarius was 72-91\%, median values.

Duration of the blanching step, type of water used and status of the mushrooms used (fresh or frozen) were without impact on the total rate of $\mathrm{Cd}$ leaching, while blanching could be more effective for frozen (decrease at $41 \%$, median value) than fresh (decrease in the range of $12-39 \%$, median values) fruiting bodies. Also, in a study by Svoboda et al. (2002), it was noted that because of boiling under reflux of sliced fruiting bodies of Imleria badia (Fr.) Vizzini (former name Xerocomus badius (Fr.) E.-J. Gilbert) for 15 to $60 \mathrm{~min}$, the rate of $\mathrm{Cd}$ leaching was higher from the frozen $(58 \%)$ than from the fresh $(36 \%)$ mushrooms, while time of boiling was without an impact.

In the case of the genus Agaricus mushrooms, pieces of a fresh Agaricus blazei Murrill from the farm, when boiled in a 
Table 1 Results of the measurements of accuracy of the analytical data using certificate reference materials "fungal-powdered fruiting bodies of by ICP-DRC-MS

\begin{tabular}{lllll}
\hline Analyte & Reference material & $\begin{array}{l}\text { Measured value } \\
\left(\mathrm{mg} \mathrm{kg}^{-1}\right)\end{array}$ & $\begin{array}{l}\text { Certified value } \\
\left(\mathrm{mg} \mathrm{kg}^{-1}\right)\end{array}$ \\
\hline $\mathrm{Cd}$ & IC-CS-M-4 & $1.43 \pm 0.13$ & $1.33 \pm 0.09$ \\
$\mathrm{Cd}$ & INCT-TL-1 & $0.030 \pm 0.004$ & $0.030 \pm 0.006$ & 107 \\
$\mathrm{Cd}$ & INCT-MPH-2 & $0.199 \pm 0.015$ & $0.194 \pm 0.008$ & 101 \\
\hline
\end{tabular}

Leccinum scabrum" IC-CS-M-4 $(n=5)$; Oriental basma tobacco leaves, INCT-OBTL-5 $(n=5)$; and mixture of Polish herbs, INCT-MPH-2 $(n=5)$ metal vessel for a period of $20 \mathrm{~min}$ leached $36 \%$ of $\mathrm{Cd}$ (Sun et al. 2012). A simple washing and deskinning of the fruiting bodies of A. bisporus in one study caused decrease of Cd content by 30-40\% (Źródłowski 1995).

Cadmium forms complexes with protein-like structures in fruiting bodies of mushrooms. This metal was identified in fruiting bodies of Agaricus macrosporus (F.H. Møller and Jul. Schäff.) Pilát (current name Agaricus urinascens (Jul. Schäff. \& F.H. Møller) Singer) in glycoprotein complex free of sulphur (Meisch and Schmitt, 1986). In mushroom Agaricus augustus Fr., Cd was in a large portion associated with water soluble ligands of a size from 55,000 to 100,000 Da (Lind et al. 1995).

Table 2 Cadmium content and its leaching rates from the household-treated C. cibarius

\begin{tabular}{|c|c|c|c|c|c|c|c|}
\hline \multirow{2}{*}{$\begin{array}{l}\text { Initial status before drying, } \\
\text { blanching and further pickling }\end{array}$} & \multicolumn{2}{|c|}{ Cd content $\left(\mathrm{mg} \mathrm{kg}^{-1} \mathrm{db}\right)$} & \multirow{2}{*}{$\begin{array}{l}\text { Treatment time } \\
\text { and type of water }\end{array}$} & \multirow{2}{*}{$\begin{array}{l}\text { Decrease } \\
\text { of Cd }(\%)\end{array}$} & \multirow{2}{*}{$\begin{array}{l}\text { Cd content } \\
\left(\mathrm{mg} \mathrm{kg}^{-1} \mathrm{db}\right) \\
\text { Pickled } \\
\text { mushrooms }\end{array}$} & \multirow{2}{*}{$\begin{array}{l}\text { Estimated rate of } \mathrm{Cd} \\
\text { decrease in relation to } \\
\text { blanched mushrooms }(\%)\end{array}$} & \multirow{2}{*}{$\begin{array}{l}\text { Total } \\
\text { decrease of } \\
\text { Cd }(\%)\end{array}$} \\
\hline & $\begin{array}{l}\text { Dried } \\
\text { mushrooms }\end{array}$ & $\begin{array}{l}\text { Blanched } \\
\text { mushrooms }\end{array}$ & & & & & \\
\hline Fresh; $2(112)^{\mathrm{a}}$ & $\begin{array}{l}0.22 \pm 0.03^{\mathrm{d}} \\
0.22 \\
0.17-0.25\end{array}$ & $\begin{array}{l}0.14 \pm 0.01 \\
0.14 \\
0.13-0.15\end{array}$ & $\begin{array}{l}5 \text { min; } \\
\text { deionized }\end{array}$ & $\begin{array}{l}36 \pm 7 \\
39 \\
25-43\end{array}$ & $\begin{array}{l}0.046 \pm 0.013 \\
0.050 \\
0.025-0.061\end{array}$ & $\begin{array}{l}43 \pm 8 \\
40 \\
35-54\end{array}$ & $\begin{array}{l}78 \pm 6 \\
76 \\
73-90\end{array}$ \\
\hline Fresh; 2 (311) & $\begin{array}{l}0.18 \pm 0.04 \\
0.19 \\
0.12-0.23\end{array}$ & $\begin{array}{l}0.13 \pm 0.03 \\
0.13 \\
0.095-0.16\end{array}$ & $\begin{array}{l}5 \text { min; } \\
\text { mineral }\end{array}$ & $\begin{array}{l}28 \pm 9 \\
27 \\
18-41\end{array}$ & $\begin{array}{l}0.035 \pm 0.009 \\
0.031 \\
0.027-0.050\end{array}$ & $\begin{array}{l}53 \pm 8 \\
57 \\
42-58\end{array}$ & $\begin{array}{l}81 \pm 4 \\
82 \\
75-86\end{array}$ \\
\hline Fresh; 3 (267) & $\begin{array}{l}0.21 \pm 0.04 \\
0.19 \\
0.17-0.27\end{array}$ & $\begin{array}{l}0.17 \pm 0.03 \\
0.17 \\
0.13-0.23\end{array}$ & $\begin{array}{l}15 \text { min; } \\
\text { mineral }\end{array}$ & $\begin{array}{l}17 \pm 9 \\
16 \\
7.1-32\end{array}$ & $\begin{array}{l}0.024 \pm 0.012 \\
0.026 \\
0.0059-0.044\end{array}$ & $\begin{array}{l}71 \pm 11 \\
67 \\
60-89\end{array}$ & $\begin{array}{l}88 \pm 7 \\
89 \\
73-97\end{array}$ \\
\hline Fresh; 2 (331) & $\begin{array}{l}0.27 \pm 0.01 \\
0.26 \\
0.26-0.28\end{array}$ & $\begin{array}{l}0.19 \pm 0.07 \\
0.22 \\
0.095-0.25\end{array}$ & $\begin{array}{l}15 \text { min; } \\
\text { deionized }\end{array}$ & $\begin{array}{l}11 \pm 7 \\
12 \\
3.7-20\end{array}$ & $\begin{array}{l}0.074 \pm 0.032 \\
0.076 \\
0.039-0.11\end{array}$ & $\begin{array}{l}61 \pm 11 \\
60 \\
47-77\end{array}$ & $\begin{array}{l}72 \pm 11 \\
72 \\
60-85\end{array}$ \\
\hline Fresh; 3 (242) & $\begin{array}{l}0.34 \pm 0.16 \\
0.27 \\
0.23-0.53\end{array}$ & $\begin{array}{l}0.27 \pm 0.13 \\
0.23 \\
0.17-0.41\end{array}$ & $\begin{array}{l}15 \text { min; } \\
\text { deionized }\end{array}$ & $\begin{array}{l}20 \pm 6 \\
22 \\
14-25\end{array}$ & $\begin{array}{l}0.030 \pm 0.004 \\
0.029 \\
0.027-0.035\end{array}$ & $\begin{array}{l}70 \pm 6 \\
71 \\
63-75\end{array}$ & $\begin{array}{l}90 \pm 3 \\
89 \\
88-93\end{array}$ \\
\hline Fresh; 3 (142) & $\begin{array}{l}0.29 \pm 0.03 \\
0.29 \\
0.27-0.32\end{array}$ & $\begin{array}{l}0.19 \pm 0.01 \\
0.19 \\
0.18-0.20\end{array}$ & $\begin{array}{l}15 \mathrm{~min} \\
\text { mineral }\end{array}$ & $\begin{array}{l}35 \pm 1 \\
35 \\
34-36\end{array}$ & $\begin{array}{l}0.027 \pm 0.013 \\
0.024 \\
0.016-0.041\end{array}$ & $\begin{array}{l}56 \pm 5 \\
56 \\
51-60\end{array}$ & $\begin{array}{l}91 \pm 4 \\
91 \\
87-94\end{array}$ \\
\hline Frozen; 6 (298) & $\begin{array}{l}0.53 \pm 0.22 \\
0.63 \\
0.22-0.75\end{array}$ & $\begin{array}{l}0.32 \pm 0.13 \\
0.37 \\
0.12-0.46\end{array}$ & $\begin{array}{l}15 \text { min; } \\
\text { deionized }\end{array}$ & $\begin{array}{l}40 \pm 6 \\
41 \\
31-53\end{array}$ & $\begin{array}{l}0.11 \pm 0.03 \\
0.11 \\
0.047-0.15\end{array}$ & $\begin{array}{l}38 \pm 7 \\
40 \\
29-48\end{array}$ & $\begin{array}{l}77 \pm 7 \\
80 \\
64-85\end{array}$ \\
\hline
\end{tabular}

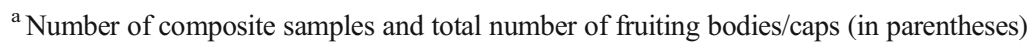

${ }^{\mathrm{b}}$ Kept for 5 or $15 \mathrm{~min}$ in gently boiling water

c They were blanched before pickling

${ }^{\mathrm{d}}$ Mean $\pm \mathrm{SD}$, median and range 
Steinhauser 2016). Nevertheless, if a tasty juice (made of a vegetable oil/butter and liquid released from the roasted fruitbodies of C. cibarius) is eaten (usually is not discarded) with bread, a possible exposure can remain at the same level. Blanching and draining of mushrooms before further cooking (with butter and using the cooking pan) can be an alternative.

Cadmium, like mercury, is a chalcophile (sulphur seeker) element but in relation to cadmium, pickling of blanched $C$. cibarius with a diluted vinegar marinade had only a minor, if any effect on removal of accumulated mercury and was without effect on blanched caps of Amanita fulva (Falandysz and Drewnowska, 2017). This probably can be explained due to difference in chemical forms observed between both elements in fruiting bodies. Mercury, which is often well accumulated by mushrooms, can form in their flesh hardly soluble inorganic compounds $(\mathrm{HgSe}, \mathrm{HgS})$ and metalorganic complexes (Vogel-Mikus et al. 2016) with relatively firm or very firm bonds.

As noted in this study, pickling of C. cibarius using a vinegar-based marinade was on the average more efficient in leaching of cadmium than blanching in $90-95^{\circ} \mathrm{C}$ using potable and deionized water. A reason could be better solubility of the cadmium complexes in acidified marinade than in nonacidified water, and in a result higher removal rate of such complex than leached in a parallel, the other organic constituents.

Cadmium is a toxic element for which contents in food (also from wild and cultivated or agricultural sites) are regulated in the European Union (EC 2006, EC 2008, EC 2014). In the case of three species of cultivated fungi, i.e. champignon mushroom (A. bisporus), oyster mushroom (Pleurotus ostreatus) and shitake (Lenintula eodes) limit for $\mathrm{Cd}$ is $0.2-\mathrm{mg} \mathrm{kg}^{-1}$ fresh product. For "other mushrooms", limit for $\mathrm{Cd}$ is $1.0-\mathrm{mg} \mathrm{kg}^{-1}$ fresh product. The consignments of $C$. cibarius in this study showed on low contamination with cadmium, which was in the total range of $0.022-0.075-\mathrm{mg} \mathrm{kg}^{-1}$ fresh biomass and medians in the range of $0.019-0.063-\mathrm{mg} \mathrm{kg}^{-1}$ fresh biomass (assuming moisture content at $90 \%$ ). Hence, regardless of a more or less contamination with cadmium, content of this element in $C$. cibarius and probably also in other mushrooms can be highly decreased after processing such as blanching and pickling, and what can highly reduce its impact on the health of a consumer.

\footnotetext{
Acknowledgements This study in part was financially supported to by the National Science Centre of Poland under call PRELUDIUM (Project no. DEC-2012/05/N/NZ9/01561).

Open Access This article is distributed under the terms of the Creative Commons Attribution 4.0 International License (http:// creativecommons.org/licenses/by/4.0/), which permits unrestricted use, distribution, and reproduction in any medium, provided you give appropriate credit to the original author(s) and the source, provide a link to the Creative Commons license, and indicate if changes were made.
}

\section{References}

Árvay J, Tomáša J, Hauptvogl M, Kopernická M, Kováčik A, Bajčan D, Massányi P (2014) Contamination of wild-grown edible mushrooms by heavy metals in a former mercury-mining area. J Environ Sci Health Part B 49:815-827

Biekman ESA, Kroese-Hoedeman HI, Schijven HPHM (1996) Loss of solutes during blanching of mushrooms (Agaricus bisporus) as a result of shrinkage and extraction. J Food Eng 28:139-152

Borovička J, Řanda Z, Jelínek E, Kotrba P, Dunn CE (2007) Hyperaccumulation of silver by Amanita strobiliformis and related species of the section Lepidella. Mycol Res 111:1339-1344

Brzezicha-Cirocka J, Mędyk M, Falandysz J, Szefer P (2016) Bio- and toxic elements in edible wild mushrooms from two regions of potentially different environmental conditions in eastern Poland. Environ Sci Pollut Res 23:21517-21522

Cen F, Chen L, Hu Y, Xu H (2012) Chelator-induced bioextraction of heavy metals from artificially contaminated soil by mushroom (Coprinus comatus). Chem Ecol 28:267-280

Coskuner Y, Özdemir Y (1997) Effect of canning processes on the elements content of cultivated mushrooms (Agaricus bisporus). Food Chem 60:559-562

Coskuner Y, Özdemir Y (2000) Acid and EDTA blanching effects on the essential element content of mushrooms (Agaricus bisporus). J Sci Food Agric 80:2074-2076

Drewnowska M, Falandysz J (2015) Investigation on minerals composition and accumulation by popular edible mushroom common Chanterelle (Cantharellus cibarius). Ecotoxicol Environ Saf 113:9-17

Drewnowska M, Falandysz J, Chudzińska M, Hanć A, Saba M, Barałkiewicz D (2017) Leaching of arsenic and sixteen metallic elements from Amanita fulva mushroom. LWT - Food Sci technol $84: 861-866$

EC (2006) Commission Regulation (EC) No 1881/2006 of 19 December 2006. Setting maximum levels for certain contaminants in foodstuffs. Off J Eur Union 364:5-24

EC (2008) Commission Regulation (EC) No 629/2008 of 2 July 2008. Amending regulation (EC) no 1881/2006 setting maximum levels for certain contaminants in foodstuffs. Off J Eur Union 173:6-9

EC (2014) Commission Regulation (EC) No 488/2014 of 12 May 2014. Amending regulation (EC) no 1881/2006 as regards maximum levels of cadmium in foodstuffs. Off J Eur Union 138:75-79

Falandysz J (2016) Mercury bio-extraction by fungus Coprinus comatus: a possible bioindicator and mycoremediator of polluted soils. Environ Sci Pollut Res 23:7444-7451

Falandysz J (2017) Mercury accumulation of three Lactarius mushroom species. Food Chem 214:96-101

Falandysz J, Drewnowska M (2015) Macro and trace elements in common Chanterelle (Cantharellus cibarius) mushroom from the European background areas in Poland: composition, accumulation, dietary exposure and data review for species. J Environ Sci Health Part B 50:374-387

Falandysz J, Drewnowska M (2017) Cooking can decrease mercury contamination of a mushroom meal: Cantharellus cibarius and Amanita fulva. Env Sci Poll Res 24:13352-13357

Falandysz J, Rizal LM (2016) Arsenic and its compounds in mushrooms: a review. J Environ Sci Health Part C 34:217-232

Falandysz J, Bona H, Danisiewicz D (1994) Silver uptake by Agaricus bisporus from an artificially enriched substrate. Zeitschr Lebensm Unters Forsch 199:225-228

Falandysz J, Szymczyk K, Ichihashi H, Bielawski L, Gucia M, Frankowska A, Yamasaki S (2001) ICP/MS and ICP/AES elemental analysis (38 elements) of edible wild mushrooms growing in Poland. Food Addit Contam 18:503-513 
Falandysz J, Lipka K, Kawano M, Brzostowski A, Dadej M, Jędrusiak A, Puzyn T (2003) Mercury content and its bioconcentration factors at Łukta and Morag, northeastern Poland. J Agric Food Chem 51:2832-2836

Falandysz J, Kunito T, Kubota R, Brzostowski A, Mazur A, Falandysz JJ, Tanabe S (2007a) Selected elements of poison Pax Paxillus involutus. J Environ Sci Health Part A 42:1161-1168

Falandysz J, Kunito T, Kubota R, Lipka K, Mazur A, Falandysz J, Tanabe S (2007b) Selected elements in fly agaric Amanita muscaria. J Environ Sci Health Part A 42:1615-1623

Falandysz J, Drewnowska M, Jarzyńska G, Zhang D, Zhang Y, Wang J (2012) Mineral constituents in common chanterelles and soils collected from a high mountain and lowland sites in Poland. J Mt Sci 9:697-705

Falandysz J, Chudzińska M, Barałkiewicz D, Drewnowska M, Hanć A (2017a) Toxic elements and bio-metals in Cantharellus mushrooms from Poland and China. Environ Sci Pollut Res 24:11472-11482

Falandysz J, Sapkota A, Dryżałowska A, Mędyk M, Feng X (2017b) Analysis of some metallic elements and metalloids composition and relationships in parasol mushroom Macrolepiota procera. Environ Sci Pollut Res 24. doi:10.1007/s11356-017-9136-9

Favero N, Bressa G, Costa P (1990) Response of Pleurotus ostreatus to cadmium exposure. Ecotox Env Saf 20:1-6

García MÁ, Alonso J, Melgar MJ (2005) Agaricus macrosporus as a potential bioremediation agent for substrates contaminated with heavy metals. J Chem Technol Biotechnol 80:325-330

García MÁ, Alonso J, Melgar MJ (2009) Lead in edible mushrooms. Levels Bioconcentration Factors. J Haz Mat 167:777-783

Kojta AK, Gucia M, Krasińska G, Saba M, Nnorom IC, Falandysz J (2016) Multivariate analysis of mineral constituents of edible field parasol (Macrolepiota procera) mushroom and soils beneath to fruiting bodies collected from an upland regions of Poland. Bioconcentration potential, intake and toxicological risk. Polish J Environ Stud 25:1-16

Lind Y, Glynn AW, Engman I, Jorhem L (1995) Bioavailability of cadmium from crab hepatopancreas and mushroom in relation to inorganic cadmium: a 9-week feeding study in mice. Food Chem Toxicol 33:667-673

Meisch HU, Schmitt JA (1986) Characterization studies on cadmiummycophosphatin from the mushroom Agaricus macrosporus. Environ Health Perspect 65:29-32

Melgar MJ, Alonso J, Perez-Lopez M, García MA (1998) Influence of some factors in toxicity and accumulation of cadmium from edible wild macrofungi in NW Spain. J Environ Sci Health Part B 33:439-455

Melgar MJ, Alonso J, García MA (2016) Cadmium in edible mushrooms from NW Spain: bioconcentration factors and consumer health implications. Food Chem Toxicol 88:13-20

Mędyk M, Chudzińska M, Barałkiewicz D (2017) Specific accumulation of cadmium and other trace elements in Sarcodon imbricatus using
ICP-MS with a chemometric approach. J Environ Sci Health Part B 52:361-366

Mleczek M, Siwulski M, Mikołajczak P, Gąsecka M, Rissmann I, Goliński P, Sobieralski K (2015a) Differences in Cu content in selected mushroom species growing in the same unpolluted areas in Poland. J Environ Sci Health Part B 50:659-666

Mleczek M, Siwulski M, Mikołajczak P, Gąsecka M, Sobieralski K, Szymańczyk M, Goliński P (2015b) Content of selected elements in Boletus badius fruiting bodies growing in extremely polluted wastes. J Environ Sci Health Part A 50:767-775

Münger K, Lerch K (1985) Copper metallothionein from the fungus Agaricus bisporus: chemical and spectroscopic properties. Biochemistry 24:6751-6756

Osobová M, Urban V, Jedelský PL, Borovička J, Gryndler M, Ruml T, Kotrba P (2011) Three metallothionein isoforms and sequestration of intracellular silver in the hyperaccumulator Amanita strobiliformis. New Phytol 90:916-926

PN-90A-7510/03 (2003) Przetwory owocowe i warzywne. Przygotowanie próbek i metody badań fizykochemicznych. Oznaczanie zawartości suchej masy metodą wagową. Polski Komitet Normalizacyjny, Warszawa

Schmitt JA, Meisch HU (1985) Cadmium in mushrooms - distribution, growth effects, and binding. Trace Elements Med 2:163-166

Skibniewska KA, Smoczyński S (1999) Wpływ obróbki kulinarnej na poziom radiocezu w grzybach. Roczn Panstw Zakł Hig 50:157-167

Stefanović V, Trifković J, Mutić J, Tešić Ž (2016) Metal accumulation capacity of parasol mushroom (Macrolepiota procera) from Rasina region (Serbia). Environ Sci Pollut Res 23:13178-13190

Steinhauser G, Steinhauser V (2016) A simple and rapid method for reducing radiocesium concentrations in wild mushrooms (Cantharellus and Boletus) in the course of cooking. J Food Prot 79:1995-1999

Svoboda L, Kalač P, Špička J, Janoušková D (2002) Leaching of cadmium, lead and mercury from fresh and differently preserved edible mushroom, Xerocomus badius, during soaking and boiling. Food Chem 79:41-45

Sun L, Liu G, Yang M, Zhuang Y (2012) Bioaccessibility of cadmium in fresh and cooked Agaricus blazei Murill assessed by in vitro biomimetic digestion system. Food Chem Toxicol 50:1729-1733

Vogel-Mikus K, Debeljak M, Kavčič A, Murn T, Arčon I, Kodre A, van Elteren JT, Budič B, Kump P, Mikuš K, Migliori A, Czyzycki M, Karydas A (2016) Localization and bioavailability of mercury and selenium in edible mushrooms Boletus edulis and Scutiger pes caprae. Abstract book of the 18th international conference on heavy metals in the environment, 12 to 15 September 2016, Ghent, Belgium, pp 611-612

Źrodłowski Z (1995) The influence of washing and peeling of mushrooms Agaricus bisporus on the level of heavy metal contamination. Polish J Food Nutr Sci 45:26-33 